\title{
Sixty seconds on ... the contact tracing app
}

\author{
Gareth lacobucci
}

The BMJ

\section{Another NHS app?}

I know it seems like we're hearing about a new one every week (particularly with such an "appy clappy" health secretary) but this one has a very specific purpose.

\section{Covid-19 ... ?}

Got it in one. This week, a new contact tracing app is being piloted on the Isle of Wight, before being rolled out more widely later this month. The free app is a key part of the government's track and trace strategy for limiting a second wave of the virus.

\section{How does it work?}

It tracks when users come into contact with each other on an automated basis, using bluetooth technology. If someone using the app develops covid-19 symptoms, disclosing this could trigger an anonymous alert to anyone they've recently had contact with (if they're also using the app).

\section{Will this be an easy Ryde?}

Not exactly. Cabinet minister Michael Gove said the government hoped more than half of households on the Isle of Wight would download the app. Ministers estimate that if around $56 \%$ of the population-or about $80 \%$ of people who own a smartphone-do this, the virus can be suppressed.

\section{What if it's lower? Wait until the Cowes come home?}

Even if take up is lower than this threshold, the government still believes that the spread of the virus could be slowed. If it can demonstrate this on the Isle of Wight, it'll seek to channel this success back across the water.

\section{But not everyone has a smartphone}

This is true, and the Labour party believes this is a flaw in the government's plan. There are also concerns around privacy and security, with some worried about how much access the government and potentially third parties will have to our personal data.

\section{Could the government do contact tracing without an app?}

There is the more traditional public health approach involving telephone calls and old fashioned legwork, and the government has promised to recruit 18000 people to do this type of manual contact tracing. But given its recent track record of delivering on numerical promises, we should probably check whether these people are actually doing contact tracing or just "have the capacity" to. 